\title{
Conceptual vision of the policy of implementing social and labor potential of the population with decentralization
}

\author{
Olga Novikova ${ }^{1}$, Yaroslav Ostafiichuk ${ }^{l}$, Olena Khandii $^{{ }^{*}}$, and Marina Deich ${ }^{2}$ \\ ${ }^{1}$ Institute of Industrial Economics, National Academy of Sciences of Ukraine, 2 Zhelyabova Street, \\ Kyiv, 03057, Ukraine \\ ${ }^{2}$ Vinnytsia Cooperative Institute, 59 Frunze St, Vinnytsya, 21009, Ukraine
}

\begin{abstract}
The article defines the conceptual vision of the policy of implementing social and labor potential of the population with decentralization, formulates its basic principles as guidelines for practical actions. Essence and role of inter-municipal cooperation for intensification of social potential of communities are revealed, possible ways of its institutional support are suggested. It is found that decentralization processes require effective instruments for coordinating interests, and social mobilization plays an important role in this, which is to involve a maximum number of people in solving community problems and participating in decision making. It is concluded that social potential may turn into a decisive factor in the development of a territorial community in the implementation of the following principles: comparativeness and competitiveness; motivation; social connections and inclusion; mutual responsibility; network availability; openness and transparency; value orientation; individual social interaction; limited solidarity.
\end{abstract}

\section{Introduction}

The decentralization reform in Ukraine is devoted to creating capable administrativeterritorial units, improving the quality of social and public services throughout the country. The purpose of decentralization is to expand the potential of territorial communities, to strengthen their motivation to self-development on the basis of the formation of an adequate institutional environment, redistribution of powers and functions of the executive power, to increase the efficiency of use of local resources and own opportunities. The process of decentralization involves providing the community with available material and financial resources to form the material and financial basis for sustainable development of territories. The financial insolvency of territorial communities over the past decades was caused, in particular, by the specifics of the national budgetary system such as the limited revenue base of local budgets and their dependence on various state transfers. At the same time, financial decentralization should be considered not as an end in itself, but as a precondition

* Corresponding author: alkhandiy@ukr.net 
and a mechanism for intensifying the social and economic potential of the community according to the "bottom-up" principle.

Focus on social potential is connected with the necessity of creating a new form of spatial organization of life - a capable united territorial community, in which the population is defined not only as inhabitants of a certain territory, but as an important social community capable, as a subject of management, of acting as a factor in social and economic development on the basis of common values and responsibility to the community [1]. Among other things, this needs to increase the level of professionalism, to overcome economic, entrepreneurial and social passivity, to develop social ties and networks. The management of sustainable development locally involves close interaction between the public, authorities, business entities, and other stakeholders, which requires an appropriate level of coordination, control and accountability between them. One of the results should be convergence of the local community, public consensus on the basis of involving all members of the community in the socio-economic processes. Ultimately, it is about building the social potential of sustainable development as a combination of opportunities, abilities, and willingness of a local community to make appropriate changes.

The aim of the study is to identify the conceptual framework and policy priorities for implementing social and labor potential with decentralization.

\section{Research results}

The content of social potential manifests itself in the level and nature of the harmonization of social relations in society as a whole, or within individual territorial communities on the basis of cooperation and partnership interactions. Realization of such relations ensures not only the efficient use of human potential, but also coordinates the social behavior of individuals within and beyond the economic activity, generating synergistic effects. The fundamental point is the recognition of the possibility of multi-directional action of social potential - it can provide development or disintegration. The quality of the formed social relationships (networks) and social institutions determines whether they are a factor of deterrence or, conversely, will contribute to the transition to a sustainable development model [2].

Creating conditions for sustainable development means overcoming barriers and accelerating engagement that extends real opportunities and freedoms for the development of an inclusive society in which diversity is a force, not a weakness. Within such a conceptual framework one can speak of processes of decentralization as processes of social attraction of communities as structured elements of society (social bodies) into a united territorial community (UTC).

The diversity of entities within the united communities increases opportunities, stimulates the development of social ties, the search for compromises, partnerships and, on this basis, the growth of the aggregate social potential. Decentralization can give the desired positive results in conditions of mobilizing social potential to address socially significant problems if it stimulates and enhances processes of participation of people in management at the regional or local levels. Otherwise, the central bureaucracy may be replaced by a local one, which, moreover, tends to be less professional. Decentralization, which is not accompanied by greater openness and the involvement of citizens in the management process, cannot be considered an effective institution for the formation of a capable territorial community.

Based on the statistically substantiated conclusion that larger communities generally have more financial resources [3-4], we assume that in addition to the positive financial effects and opportunities for developing social infrastructure, larger in size and quantity UTCs increasingly own other, not connected only with financial and technical 
preconditions, possibilities of building up, intensifying and realizing social potential, considered in the plane of the diversification of tools of interaction and constructive cooperation between subjects of UTC.

This statement follows from the concepts of social inclusion / engagement and social exclusion. Inclusion in the broad socio-philosophical sense is understood as a form of the common existence of many ordinary people, within which all interested parties should take an active part in obtaining the desired result [5]. As already mentioned, the field of social potential is heterogeneous. The difference in the potentials of different points in the social field generates tension. On the one hand, social tension of a certain degree and character intensifies the search for new variants and forms of involvement in social potential; on the other hand, an increase in social tension and its disorienting nature lead to the search for ways to destroy social potential or its localization. The diversity of subjects in the UTC (individuals, social groups, communities) expands opportunities, stimulates the development of social ties, the search for compromises, partnerships and, on this basis, the growth of the total social potential of UTC, while it increases the range of risks of decentralization that needs an adequate risk management system.

In this context, one of the areas of strengthening and implementing social potential is the cooperation of local communities (inter-municipal cooperation). According to the Law of Ukraine "On cooperation of local communities" it is a relationship between two or more territorial communities on a contractual basis in certain forms for the socio-economic and cultural development of the area, improvement of the quality of public services on the basis of common interests and goals, effective execution of the powers determined by the law by local self-government bodies. Taking into consideration this feature, one can conclude that cooperation as mutually beneficial relationships of interested parties has its logically justified ultimate meaning, that is the outcome, for which municipalities entered into a relationship on a contractual basis. This means that statutory mechanisms of combining existing resources of local communities should lead to more effective implementation of the powers defined by the law by local government, which in turn should provide socioeconomic and cultural development of areas, increase the quality of public services on the basis of common interests and goals.

Accordingly, the most important in the cooperation of communities is a principle of mutual benefit, one of the most widely recognized principles of international law, which is closely linked with the principle of equality of the actors. After all, only within the framework of equality it is possible to take into account mutual interests in order to achieve mutual benefits. Therefore, in the Charter of Economic Rights and Duties of the States of 1974 , these principles are regarded as complementary.

Another important principle is the principle of equality of actors, which means formal equality, i.e., the identity of the scope of rights and legally authorized opportunities of the parties to the legal relationship. The principle is expressed in the concepts of formal equality, prohibition of discrimination, lack of groundless, unfounded advantages or privileges for any of the actors of cooperation. Any of the actors has equal rights with regard to other actors during the organization and implementation of the cooperation itself, in spite of the size of the territory of the territorial community, the size of the budget, the number of inhabitants, the geographical location, the existing infrastructure, etc. This principle is relevant, given the need to protect the interests of peripheral rural communities within the framework of large-scale urban UTCs.

Based on the concept «rural-urban partnerships» OECD [6-7], Borodina O., A.Tkachuk and others [8-9] point to the priority for Ukraine considering the problems of cooperation of territorial communities in the format "city-village". "The essence of the idea is to organize cooperation between urban and rural areas on the basis of mutually beneficial cooperation, the division of powers, the use of existing advantages in order to bring rural areas closer to 
sources of concentration of innovation, social and financial capital, investments, social and transport infrastructure objects typical of urban settlements, together with more active involvement of rich resources of rural areas to processes of social production" [9].

Today domestic legislation on the cooperation of territorial communities regulates various types of cooperation that correspond to European practice and relate exclusively to voluntary cooperation. At the same time, it does not imply cases of compulsory cooperation between communities existing in different European countries. There are five forms in which communities can cooperate: 1) cooperation in the form of delegation to one of the actors of cooperation by other actors of cooperation to carry out one or more tasks with the transfer of appropriate resources to them; 2) cooperation in the form of joint projects implementation; 3) cooperation in the form of co-financing (maintenance) of enterprises, institutions and organizations of communal form of ownership - infrastructure objects by actors of cooperation; 4) cooperation in the form of the formation of joint communal enterprises, institutions and organizations - joint infrastructural objects by actors of cooperation; 5) cooperation in the form of the formation of a joint management body by actors of cooperation for joint implementation of the powers determined by the law.

As of March 20, 2019, 368 agreements were registered in the Register of Treaties on the Cooperation of Territorial Communities [10]. The analysis shows that most often problems of removal and disposal of solid household wastes, water supply and drainage in cities and suburban areas are solved in this way, but projects aimed at creating a complete cycle of collection, sorting, recycling and disposal of waste are only isolated cases. A practice of implementing projects aimed at developing social networks and forming a common social space in the united communities has not become widespread (conducting appropriate training activities, trainings, as well as joint activities, for example, joint tree planting in the forest or on the hills on the edge of communities improves mutual understanding). There are practically no projects of cooperation on creation of business incubators or other modern centers of entrepreneurial activity development, which is very important from the point of view of implementing the labor potential of communities on innovative grounds.

Thus, the cooperation of territorial communities is significant for intensifying the social potential of sustainable development at the local level through participatory democracy, implementation of social mobilization measures, more active involvement of citizens in solving local issues and strengthening interaction between the authorities and community. It is clear that the identification of possible topics for cooperation should begin with active consultations with citizens, studying the most urgent problems for inhabitants. Public discussions, hearings, consultations with community members are an essential element of the development of cooperation.

For Ukraine, the following three models of institutional support for the development of cooperation of territorial communities are the most feasible:

- creation of a resource center for the development of cooperation at the state authorities, in particular at the Ministry of Regional Development, Construction and Housing and Communal Services of Ukraine, which is the central executive body authorized to implement the reform of local self-government and development of cooperation of territorial communities;

- creation of a resource center of support at the associations of local self-government bodies. Such centers are established in France, Belgium and other countries;

- creation and development of a resource center as a non-governmental public organization [11].

Based on the experience of some European countries (in particular, Germany, Belgium), resource centers ("centers of competence") on cooperation of territorial communities at the regional and local levels may be useful. For instance, in the federal state of Hessen (Germany), a directive was adopted on promoting inter-municipal cooperation (Framework 
Agreement), which sets out the goals and procedures for the facilitation. The Hessian Ministry of the Interior and Sports has established a Department for Inter-municipal Cooperation and an appropriate Center of Competence with the participation of the Association of Cities and Communities. The main areas of responsibility of the Center of Competence include strategy and definition of the content of inter-municipal cooperation, community counseling, preparation and implementation of information activities for the purpose of involving citizens and local authorities, development of appropriate methodological recommendations, brochures and publications, development and collection of information materials on opportunities for inter-municipal cooperation [11].

Social relations provide the interaction of all components of social potential. They help to identify and implement ways to systematically formulate and effectively use social potential. The development of social relations in this direction requires appropriate changes in social institutions. The growth of human consciousness in the system of social relations promotes the intensification of activity in this area, provides conditions for the transformation of opportunities and readiness of social potential for real actions.

The basic provision of the policy of realizing social potential is the provision of social mobilization of the population. Social mobilization is defined as the active involvement of all strata of the population (or of individual social groups) in addressing the priority community problems. It is aimed at increasing social activity and responsibility of the population, members of the territorial community, integrates its separate segments in the form of partnership and cooperation for the achievement of the common goal, leads to active participation of citizens in the processes of urban development. Social mobilization is possible under the condition of maximum engagement of citizens in decision-making. Involving the population in the management of the community allows one to increase the transparency of the management processes, including budget, and take into account the citizens' will. Thus, in general terms, social potential can turn into a determining factor in the development of a territorial community in the implementation of the following principles: comparability and competition; motivation; social connections and inclusion; mutual responsibility; network availability; openness and transparency; value orientation; individual social interaction; limited solidarity, i.e. compliance with the norms of support.

We believe that one of the conditions for the success of the decentralization reform in Ukraine is the strategic orientation of UTC to the development goals. Among other things, they include the financing and implementation of activities focused on business development and employment creation. As the analysis shows, most UTCs have significant employment constraints. This is largely due to such a challenge for the sustainable development of territorial communities as migration. In its turn, it raises a number of problems, including: reducing the activity of residents, included their participation in UTC issues, development planning, involvement in projects, as the most active members of a community with a high social potential often leave, while those who remain are passive and unprotected; lack of skilled personnel in the apparatus, which is a logical consequence of the decrease in the activity of local residents, significant demographic losses. The problem of migration beyond UTC is important for all types of communities, but it is most relevant for rural UTCs remote from cities.

\section{Conclusion}

Based on the assessment of current trends in the processes of decentralization of power, we consider it necessary to focus on such conceptual principles as guidelines for practical actions:

- mechanisms for stimulating decentralization processes should include both the creation of conditions for the formation of social potential, in particular through the 
development of social infrastructure and the expansion of the range of relevant services and conditions for its implementation, including in relation to the labor potential of the community. Providing benefits exclusively to projects with a purely social effect (currently prevalent) is, in the long run, associated with the risk of losing both social and labor potential, in particular in connection with the migration of young people, who will be deprived of opportunities for productive employment, their loss of professional skills and development on this basis, destructive changes in social potential;

- in addition to promoting individual entrepreneurial activity in the communities (in particular by facilitating business conditions), it is appropriate to focus on the opportunities and tools for the development of joint local entrepreneurship, the formation of a community as an active and interested subject of economic processes using innovative approaches to attracting labor potential and multiplying on this basis the constructive social potential of the community.

The development of new approaches to community self-development is one of the key tasks of decentralization policy, since, in our view, not only budgeting or business involvement, but first and foremost, the inclusion of the existing potential, its joint usage by the population is the basis of the community's economy and its sustainable development;

- the basis for the establishment of local labor markets is the development of cooperation of territorial communities (inter-municipal cooperation) as a tool for balancing labor demand and supply, as well as a social dialogue on a new institutional basis with the widest possible inclusion of various social actors in the process of achieving agreed goals in social and labor relations. This implies the transition from the formula "state - business trade unions (employees)" to a wider institutional format of social interaction "state business - society - community".

\section{References}

1. O. Novikova, O. Amosha, V. Antonyuk, V. Vishnevsky, Social Resources for Decentralization of Management: Mechanisms for Mobilization and Effective Use (2018)

2. O. Novikova, Ya. Ostafiichuk, O. Khandii, Mechanism of Strengthening Social and Labor Potential of Sustainable Development, Problemy Ekorozwoju, vol.14, 1, 63-72 (2019)

3. Budget analysis of 665 AHs over 2018, URL: https://decentralization.gov.ua/news/10649 (2019)

4. Budget analysis of 665 AHs over 2018 in terms of oblasts, URL: https://decentralization.gov.ua/en/news/10674 (2019)

5. D. Acemoglu, J. A. Robinson, Why Nations Fail: The Origins of Power, Prosperity, and Poverty Paperback (Crown Business, New York, 2013).

6. Rural-Urban Partnerships: An Integrated Approach to Economic Development, URL: http://www.oecd.org/regional/regional-policy/rural-urban-partnerships-9789264204812-en.htm. (2013)

7. Governing rural-urban partnerships: lessons from the field, URL: http://www.oecd.org/cfe/regional-policy/Session\%20III\%20presentations.pdf (OECD, 2013)

8. O. Borodina, O. Shubravska, Agrarian and rural development for the growth and renewal of the Ukrainian economy (2018)

9. A. Tkachuk, O. Sergienko, O. Latsko, Overview of the situation regarding the implementation of partnership between urban and rural communities in conditions of decentralization and changes in the state regional policy in Ukraine: analytical note (2019)

10. Register of Territorial Communities Cooperation Agreements, URL: http://www.minregion.gov.ua/napryamki-diyalnosti/regional-dev/rozvytok-mistsevohosamovryaduvannya/reyestr (2019)

11. Cooperation of territorial communities (inter-municipal cooperation-MMC): Educational and practical manual, V. Tolkovanova, T. Zhuravlya (ed.), 80-81 (2016) 